\title{
Unspecific post-mortem findings despite multiorgan viral spread in COVID-19 patients
}

Myriam Remmelink', Ricardo De Mendonça', Nicky D’Haene', Sarah De Clercq ${ }^{1}$, Camille Verocq ${ }^{1}$, Laetitia Lebrun ${ }^{1}$, Philomène Lavis ${ }^{1}$, Marie-Lucie Racu', Anne-Laure Trépant ${ }^{1,2}$, Calliope Maris', Sandrine Rorive ${ }^{1,2}$, Jean-Christophe Goffard ${ }^{3}$, Olivier De Witte ${ }^{4}$, Lorenzo Peluso ${ }^{5}$, Jean-Louis Vincent ${ }^{5}$, Christine Decaestecker ${ }^{6,7}$, Fabio Silvio Taccone ${ }^{5}$ and Isabelle Salmon ${ }^{1,2,7^{*}}$

\begin{abstract}
Background: Post-mortem studies can provide important information for understanding new diseases and small autopsy case series have already reported different findings in COVID-19 patients.

Methods: We evaluated whether some specific post-mortem features are observed in these patients and if these changes are related to the presence of the virus in different organs. Complete macroscopic and microscopic autopsies were performed on different organs in 17 COVID-19 non-survivors. Presence of SARS-CoV-2 was evaluated with immunohistochemistry $(\mathrm{IHC})$ in lung samples and with real-time reverse-transcription polymerase chain reaction (RT-PCR) test in the lung and other organs.

Results: Pulmonary findings revealed early-stage diffuse alveolar damage (DAD) in 15 out of 17 patients and microthrombi in small lung arteries in 11 patients. Late-stage DAD, atypical pneumocytes, and/or acute pneumonia were also observed. Four lung infarcts, two acute myocardial infarctions, and one ischemic enteritis were observed. There was no evidence of myocarditis, hepatitis, or encephalitis. Kidney evaluation revealed the presence of hemosiderin in tubules or pigmented casts in most patients. Spongiosis and vascular congestion were the most frequently encountered brain lesions. No specific SARS-CoV-2 lesions were observed in any organ. IHC revealed positive cells with a heterogeneous distribution in the lungs of 11 of the 17 (65\%) patients; RT-PCR yielded a wide distribution of SARS-CoV-2 in different tissues, with 8 patients showing viral presence in all tested organs (i.e., lung, heart, spleen, liver, colon, kidney, and brain).
\end{abstract}

Conclusions: In conclusion, autopsies revealed a great heterogeneity of COVID-19-associated organ injury and the remarkable absence of any specific viral lesions, even when RT-PCR identified the presence of the virus in many organs.

Keywords: COVID-19, SARS-CoV-2, Autopsy, RT-PCR, Immunohistochemistry

\footnotetext{
*Correspondence: Isabelle.Salmon@erasme.ulb.ac.be

${ }^{1}$ Department of Pathology, Erasme Hospital, Université Libre de Bruxelles (ULB), Route de Lennik 808, 1070 Brussels, Belgium

${ }^{2}$ Centre Universitaire inter Régional d'expertise en Anatomie Pathologique Hospitalière (CurePath, CHIREC, CHU Tivoli, ULB), Rue de Borfilet 12A, 6040 Jumet, Belgium

Full list of author information is available at the end of the article
}

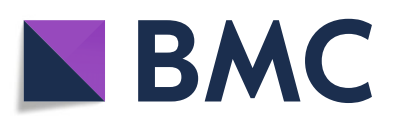

(- The Author(s). 2020 Open Access This article is licensed under a Creative Commons Attribution 4.0 International License, which permits use, sharing, adaptation, distribution and reproduction in any medium or format, as long as you give appropriate credit to the original author(s) and the source, provide a link to the Creative Commons licence, and indicate if changes were made. The images or other third party material in this article are included in the article's Creative Commons licence, unless indicated otherwise in a credit line to the material. If material is not included in the article's Creative Commons licence and your intended use is not permitted by statutory regulation or exceeds the permitted use, you will need to obtain permission directly from the copyright holder. To view a copy of this licence, visit http://creativecommons.org/licenses/by/4.0/. The Creative Commons Public Domain Dedication waiver (http://creativecommons.org/publicdomain/zero/1.0/) applies to the data made available in this article, unless otherwise stated in a credit line to the data. 


\section{Background}

Coronaviruses, including severe acute respiratory syndrome coronavirus (SARS-CoV) and Middle East respiratory syndrome coronavirus (MERS-CoV), cause severe acute respiratory failure, which is associated with high mortality rates [1]. The novel SARS-CoV-2 strain exhibits phylogenetic similarities to SARS-CoV and causes coronavirus disease 2019 (COVID-19), which has resulted in more than 540,000 deaths worldwide so far. As the pandemic has progressed, the pathophysiology of this viral infection has become clearer; in particular, it has been shown that SARS-CoV-2 can directly alter cell function by a link to the angiotensin converting enzyme 2 (ACE2) receptor, which is almost ubiquitous in the human body [2].

Nevertheless, the mechanisms behind the high mortality and severe organ dysfunction associated with COVID-19 remain poorly understood. Controversies exist regarding the occurrence of fatal complications, such as pulmonary embolism or diffuse endothelial injury [3, 4], as well as on the roles of direct viral cellular injury or concomitant comorbidities in the fatality of this disease [5].

In this setting, autopsy is of great importance to help physicians understand the biological characteristics and the pathogenesis of COVID-19. Most of the previously reported post-mortem findings focused on lung morphology and few data are available on complete post-mortem analyses of other organs $[6,7]$. The aim of this study was therefore to investigate the presence of specific features of viral injury as well as the distribution of the virus in different organs of patients who died from COVID-19.

\section{Methods}

\section{Study design}

In this post-mortem study, we included the first 17 adult patients ( $>18$ years) who died in our hospital (either in a COVID-19 unit or an intensive care unit) from March 13, 2020, with confirmed SARS-CoV-2 infection (i.e., positive RT-PCR assay on nasopharyngeal swab and/or bronchoalveolar lavage specimen). Exclusion criteria were lack of family consent and a delay of more than 5 days after death before post-mortem examination. The study protocol was approved by the local ethics committee (P2020/218).

\section{Data collection}

We collected demographics, comorbidities, relevant clinical data, including duration between symptom onset or hospitalization and death, the results of chest computed tomography scan, and, if available, microbiological tests and medical treatments (e.g., hydroxychloroquine, antivirals or antibiotics, and use of organ support). Acute respiratory distress syndrome (ARDS) and acute kidney injury (AKI) were defined according to standard definitions $[8,9]$.

\section{Post-mortem procedure}

The Belgian Public Health Institute (Sciensano) guidelines were integrated into our post-mortem procedure [10]. The cadavers were kept in the refrigerator at $4{ }^{\circ} \mathrm{C}$ and autopsies were performed 72 to $96 \mathrm{~h}$ after death to ensure the safety of the autopsy team. Personal protective equipment consisted of two superposed disposable latex gloves, plastic sleeves, FFP3 mask, scrub hat, clear face visor, surgical gown plus plastic apron, and rubber boots. In the post-mortem room, dirty and clean circulations were used in the airlocks to allow decontamination. All analyses were performed at normal pressure.

Using standard surgical pathology processing, complete sets of tissue samples were collected for diagnosis and biobanking. The material was biobanked by Biobanque Hôpital Erasme-ULB (BE_BERA1), CUB Hôpital Erasme; BBMRI-ERIC. The banked material consists of 6 samples per organ, including the trachea, thyroid, lymph nodes, heart, spleen, bone marrow, kidney, bladder, liver, stomach, colon, and brain. For the lungs, we collected six samples per lobe (i.e., a total of 30 samples), except for two patients who had undergone lobectomy for cancer and from whom only 18 samples were taken. For safety reasons, complete brain removal was not allowed, but, with the help of a neurosurgeon, in 11 cases, we used a new, safe procedure with drills and protective devices to avoid air dispersion, to obtain between 12 and 51 samples from different brain regions, as detailed in the Additional file 1 (Additional Material). Formalinfixed paraffin-embedded (FFPE) tissues underwent standard processing to provide hematoxylin and eosin (H\&E)-stained sections. Special stains and immunohistochemistry (IHC) were used for lung (Masson's trichrome, periodic acid-Schiff [PAS], Gomori-Grocott, anti-CMV IHC, anti-HSV IHC, anti-Pneumocystis J IHC) and kidney (PAS, Masson's trichrome, Jones methenamine silver) samples.

\section{Morphological analysis}

Morphological analysis was performed on H\&E stained glass slides using the SecundOs digital platform (TribVn Health Care, Chatillon, France) for digital diagnosis, after the acquisition of whole slide digital scans $(\times 40$ magnification) using a Nanozoomer 2.0 HT slide scanner (Hamamatsu, Hamamatsu City, Japan).

\section{SARS-CoV-2 detection by immunohistochemistry}

Since no antibody against SARS-CoV-2 has been validated for IHC on FFPE tissues, we selected an anti-SARSnucleocapsid protein antibody. Standard IHC was applied as previously described to 4 - $\mu$ m-thick post-mortem lung sections (one sample for each lung lobe per patient) to display SARS-nucleocapsid protein (Invitrogen, PA1-41098, dilution 1:50) on Dako Omnis (Agilent Technologies, 
Santa Clara, CA, USA) using the Envision Flex detection system according to the manufacturer's protocol [11]. The sections were counterstained with hematoxylin. Negative tissue controls were obtained from patients who had an autopsy before the COVID19 pandemic. Semi-quantitative IHC evaluation was performed by two senior pathologists (ND, MR) as follows: negative (-); between one and five positive cells per whole slide (scattered cells, + ); more than five cells per whole slide but no foci (isolated cells, ++ ); and with foci (more than 10 cells in one $\times 20$ field, +++ ).

\section{SARS-CoV-2 detection by rRT-PCR}

Total nucleic acid was extracted from FFPE tissues using the Maxwell RSC DNA FFPE Kit (reference: AS1450. Promega Corporation, Madison, WI, USA) and the Promega Maxwell extractor, following the protocol described by the manufacturer. One-step RT-PCR assays specific for the amplification of SARS-CoV-2 E envelope protein gene were adapted from a published protocol [12]. Briefly, $4 \mu \mathrm{L}$ of RNA (100 ng) was amplified in $20 \mu \mathrm{L}$ reaction mixture containing $5 \mu \mathrm{L}$ of TaqMan Fast Virus 1-step master mix (Life Technologies), $0.4 \mu \mathrm{M}$ of each forward (ACAGGTACGTTAATAGTTAATAGC GT) and reverse (ATATTGCAGCAGTACGCACACA) primers and $0.2 \mu \mathrm{M}$ of probe (FAM-ACACTAGCCA TCCTTACTGCGCTTCG-BBQ). The amplification condition was $50^{\circ} \mathrm{C}$ for $10 \mathrm{~min}$ for reverse transcription, followed by $95^{\circ} \mathrm{C}$ for $20 \mathrm{~s}$ and then 45 cycles of $95^{\circ} \mathrm{C}$ for $3 \mathrm{~s}$ and $58^{\circ} \mathrm{C}$ for $30 \mathrm{~s}$. A clinical sample highly positive for SARS-CoV-2 was diluted 1:1000 and used as a positive control in each analysis. A clinical sample obtained from a patient who was autopsied before the COVID-19 pandemic was used as a negative control. The quality of the RNA from the samples showing negative results was assessed by amplification of the human MET RNA according to a validated ISO:15189 accredited method used as a routine diagnostic method in our laboratory.

\section{Statistical analysis}

Data are reported as counts (percentage) or medians [interquartile ranges (IQRs)]. All data were analyzed using GraphPad Prism Version 8.4.2 (GraphPad Software, San Diego, CA, USA).

\section{Results}

\section{Study cohort}

The main characteristics of the study cohort (12 males out of 17; median age 72 [62-77] years) are given in Table 1 . The time period between the onset of symptoms and death ranged from 2 to 40 days (median, 14 days) and between admission and death from 0 to 33 days (median, 10 days). All except two patients had at least one comorbidity, including hypertension $(n=10)$, diabetes $(n=9)$, cerebrovascular disease $(n=4)$, coronary artery disease $(n=4)$, and solid cancer $(n=4)$. None of the patients had tested positive on admission for the respiratory syncytial virus or influenza A and B viruses. Eleven of the patients were treated with mechanical ventilation. Eleven patients died in the ICU and 6 on the medical ward; the main causes of death were respiratory failure $(n=9)$ and multiple organ failure $(n=7)$. Laboratory data are reported in Additional file 2 (Table S1).

\section{Macroscopic findings}

One patient had had a left pneumonectomy and one patient a right bilobectomy. The lungs were typically heavy and the lung parenchyma had a diffuse firm consistency with red/tan and patchy dark/red areas of hemorrhage. Thrombi were found in the large pulmonary arteries in 2 patients and lung infarction in 4 patients. Pleural adhesions associated with pleural effusions were observed in 4 cases. We observed cardiomegaly in 14 and hepatomegaly in 5 patients. The kidneys were often enlarged, with a pale cortex and petechial aspect but no hemorrhage or infarct. The gut had advanced post-mortem autolysis with no evidence of specific lesions, except for one patient who had ischemic enteritis. In the 11 patients for whom brain samples were available, one had had a recently drained subdural hematoma and another a cerebral hemorrhage.

\section{Microscopic findings}

As shown in Figs. 1 and 2 and Additional file 3 (Table S2), the main pulmonary findings included early-stage diffuse alveolar damage (DAD), which consisted of interstitial and intra-alveolar edema, with variable amounts of hemorrhage and fibrin deposition, hyaline membranes, minimal interstitial mononuclear inflammatory infiltrate, and type II pneumocyte hyperplasia. Microthrombi were noted in the small pulmonary arteries in 11 patients. Ten of the 17 patients also had advanced DAD lesions (i.e., fibroblastic proliferation within the interstitium and in the alveolar spaces); 8 patients had evidence of acute pneumonia or bronchopneumonia, 4 had atypical pneumocytes, and three had syncytial multinucleated giant cells. We observed no viral inclusions or squamous metaplasia.

All the patients who survived more than 3 weeks $(n=5)$ had late DAD lesions. There was no relationship between the delay from onset of symptoms to death or from hospitalization to death and the presence of other histological lesions, including bronchopneumonia, pneumonia, microthrombi, ischemic lesions, pulmonary emboli, or pulmonary infarct. In 4 of the 6 patients who had not received mechanical ventilation, the delay between hospitalization and death was less than 5 days; in this group, only 1 case had microthrombi. The other 2 patients had longer 
Table 1 Characteristics of the study population

\begin{tabular}{|c|c|c|c|c|c|c|c|c|c|}
\hline ID & Age & Sex & Comorbidities & CT scan & rRT-PCR & $\begin{array}{l}\text { Time to } \\
\text { death }\end{array}$ & $\begin{array}{l}\text { Ante-mortem } \\
\text { organ failure }\end{array}$ & Treatments & Cause of death \\
\hline 1 & 77 & M & $\begin{array}{l}\text { CAD } \\
\text { CVD } \\
\text { Diabetes }\end{array}$ & NEG & POS & 3 & $\begin{array}{l}\text { ARDS } \\
\text { AKI }\end{array}$ & $\begin{array}{l}\text { Mechanical } \\
\text { ventilation } \\
\text { Antibiotics }\end{array}$ & $\begin{array}{l}\text { Cardiogenic } \\
\text { shock } \\
\text { MOF }\end{array}$ \\
\hline 2 & 91 & $\mathrm{~F}$ & $\begin{array}{l}\text { Hypertension } \\
\text { CAD } \\
\text { CRF } \\
\text { Liver cirrhosis }\end{array}$ & NEG & POS & 15 & $\begin{array}{l}\text { ARDS } \\
\text { AKI } \\
\text { Hypoxic } \\
\text { hepatitis }\end{array}$ & $\begin{array}{l}\text { Hydroxychloroquine } \\
\text { Antibiotics } \\
\text { Corticosteroids }\end{array}$ & Respiratory failure \\
\hline 3 & 68 & M & $\begin{array}{l}\text { COPD } \\
\text { Cancer }\end{array}$ & GGO & POS & 15 & $\begin{array}{l}\text { ARDS } \\
\text { AKI }\end{array}$ & $\begin{array}{l}\text { Mechanical ventilation } \\
\text { Hydroxychloroquine } \\
\text { Lopinavir/Ritonavir } \\
\text { Antibiotics }\end{array}$ & Respiratory failure \\
\hline 4 & 64 & $\mathrm{~F}$ & $\begin{array}{l}\text { Hypertension } \\
\text { Cancer } \\
\text { CVD }\end{array}$ & MA & POS & 8 & ARDS & $\begin{array}{l}\text { Mechanical ventilation } \\
\text { Hydroxychloroquine } \\
\text { Antibiotics }\end{array}$ & Respiratory failure \\
\hline 5 & 56 & M & $\begin{array}{l}\text { COPD } \\
\text { Cancer }\end{array}$ & GGO & POS & 14 & $\begin{array}{l}\text { ARDS } \\
\text { AKI } \\
\text { Hypoxic } \\
\text { hepatitis }\end{array}$ & $\begin{array}{l}\text { Mechanical ventilation } \\
\text { ECMO } \\
\text { RRT } \\
\text { Hydroxychloroquine } \\
\text { Lopinavir/Ritonavir } \\
\text { Antibiotics }\end{array}$ & $\begin{array}{l}\text { Mesenteric } \\
\text { ischemia } \\
\text { MOF }\end{array}$ \\
\hline 6 & 73 & M & $\begin{array}{l}\text { Hypertension } \\
\text { CRF }\end{array}$ & $B C$ & POS & 11 & $\begin{array}{l}\text { ARDS } \\
\text { AKI }\end{array}$ & $\begin{array}{l}\text { Mechanical ventilation } \\
\text { ECMO } \\
\text { Hydroxychloroquine } \\
\text { Remdesivir } \\
\text { Corticosteroids } \\
\text { Antiobiotics }\end{array}$ & Respiratory failure \\
\hline 7 & 56 & M & None & $\mathrm{BC}$ & POS & 7 & $\begin{array}{l}\text { ARDS } \\
\text { AKI } \\
\text { Hypoxic } \\
\text { hepatitis }\end{array}$ & $\begin{array}{l}\text { Hydroxychloroquine } \\
\text { Antibiotics }\end{array}$ & Respiratory failure \\
\hline 8 & 66 & M & $\begin{array}{l}\text { Hypertension } \\
\text { CAD } \\
\text { CVD } \\
\text { CRF } \\
\text { Diabetes }\end{array}$ & Emphysema & POS & 14 & AKI & Antibiotics & $\begin{array}{l}\text { Septic shock } \\
\text { MOF }\end{array}$ \\
\hline 9 & 49 & $\mathrm{~F}$ & $\begin{array}{l}\text { Hypertension } \\
\text { Diabetes }\end{array}$ & GGO & POS & 17 & $\begin{array}{l}\text { ARDS } \\
\text { AKI }\end{array}$ & $\begin{array}{l}\text { Mechanical ventilation } \\
\text { RRT } \\
\text { Hydroxychloroquine } \\
\text { Lopinavir/Ritonavir } \\
\text { Antibiotics }\end{array}$ & Respiratory failure \\
\hline 10 & 63 & M & $\begin{array}{l}\text { Hypertension } \\
\text { Diabetes }\end{array}$ & $\begin{array}{l}\mathrm{GGO} \\
\mathrm{BC}\end{array}$ & POS & 16 & $\begin{array}{l}\text { ARDS } \\
\text { AKI }\end{array}$ & $\begin{array}{l}\text { Mechanical ventilation } \\
\text { ECMO } \\
\text { RRT } \\
\text { Hydroxychloroquine } \\
\text { Oseltamivir } \\
\text { Antibiotics }\end{array}$ & Respiratory failure \\
\hline 11 & 76 & M & $\begin{array}{l}\text { Diabetes } \\
\text { Liver cirrhosis } \\
\text { Cancer } \\
\text { Diabetes }\end{array}$ & $B C$ & POS & 5 & ARDS & $\begin{array}{l}\text { Hydroxychloroquine } \\
\text { Antibiotics }\end{array}$ & Sudden death \\
\hline 12 & 75 & M & $\begin{array}{l}\text { Hypertension } \\
\text { CAD } \\
\text { Diabetes }\end{array}$ & GGO & POS & 6 & $\begin{array}{l}\text { ARDS } \\
\text { AKI } \\
\text { Hypoxic } \\
\text { hepatitis }\end{array}$ & $\begin{array}{l}\text { Mechanical ventilation } \\
\text { Hydroxychloroquine } \\
\text { Antibiotics }\end{array}$ & MOF \\
\hline 13 & 73 & M & Diabetes & $\begin{array}{l}\mathrm{GGO} \\
\mathrm{BC}\end{array}$ & POS & 10 & ARDS & Hydroxychloroquine & Respiratory failure \\
\hline 14 & 77 & $\mathrm{~F}$ & $\begin{array}{l}\text { Hypertension } \\
\text { Diabetes }\end{array}$ & $\begin{array}{l}\mathrm{GGO} \\
\mathrm{BC}\end{array}$ & POS & 9 & $\begin{array}{l}\text { ARDS } \\
\text { AKI } \\
\text { Hypoxic } \\
\text { hepatitis }\end{array}$ & $\begin{array}{l}\text { Hydroxychloroquine } \\
\text { Antibiotics }\end{array}$ & Respiratory failure \\
\hline
\end{tabular}


Table 1 Characteristics of the study population (Continued)

\begin{tabular}{|c|c|c|c|c|c|c|c|c|c|}
\hline ID & Age & Sex & Comorbidities & CT scan & rRT-PCR & $\begin{array}{l}\text { Time to } \\
\text { death }\end{array}$ & $\begin{array}{l}\text { Ante-mortem } \\
\text { organ failure }\end{array}$ & Treatments & Cause of death \\
\hline 15 & 61 & $M$ & & $\begin{array}{l}\text { GGO } \\
\text { LP }\end{array}$ & POS & 31 & $\begin{array}{l}\text { ARDS } \\
\text { AKI } \\
\text { Pulmonary } \\
\text { embolism }\end{array}$ & $\begin{array}{l}\text { Mechanical ventilation } \\
\text { RRT } \\
\text { Hydroxychloroquine } \\
\text { Remdesivir } \\
\text { Antibiotics }\end{array}$ & $\begin{array}{l}\text { Septic shock } \\
\text { MOF }\end{array}$ \\
\hline 16 & 70 & $\mathrm{~F}$ & $\begin{array}{l}\text { Hypertension } \\
\text { Diabetes } \\
\text { Liver transplant }\end{array}$ & GGOBC & POS & 19 & $\begin{array}{l}\text { ARDS } \\
\text { AKI } \\
\text { Pulmonary } \\
\text { embolism }\end{array}$ & $\begin{array}{l}\text { Mechanical ventilation } \\
\text { RRT } \\
\text { Hydroxychloroquine } \\
\text { Antibiotics }\end{array}$ & $\begin{array}{l}\text { Septic shock } \\
\text { MOF }\end{array}$ \\
\hline 17 & 53 & M & $\begin{array}{l}\text { Hypertension } \\
\text { CVD }\end{array}$ & $\begin{array}{l}\text { GGO } \\
\mathrm{BC} \\
\mathrm{LP}\end{array}$ & POS & 13 & $\begin{array}{l}\text { ARDS } \\
\text { AKI } \\
\text { Pulmonary } \\
\text { embolism }\end{array}$ & $\begin{array}{l}\text { Mechanical ventilation } \\
\text { ECMO } \\
\text { RRT } \\
\text { Hydroxychloroquine } \\
\text { Antibiotics }\end{array}$ & $\begin{array}{l}\text { Septic shock } \\
\text { MOF }\end{array}$ \\
\hline
\end{tabular}

Time to death time from admission to death (days). Cause of death was reported by the attending physician. $M$ male, $F$ female, $r R T$ - $P C R$ reverse transcription realtime polymerase chain reaction used as diagnostic laboratory test, NEG negative, $P O S$ positive, $C A D$ coronary artery disease, $C V D$ cerebrovascular disease, $L P$ lobar pneumonia, GGO ground-glass opacity, MA minor abnormalities, $B C$ bilateral consolidation, COPD chronic obstructive pulmonary disease, $C R F$ chronic renal failure, $A R D S$ acute respiratory distress syndrome, $A K I$ acute kidney injury, ECMO extracorporeal membrane oxygenation, $R R T$ renal replacement therapy, $M O F$ multiple organ failure

delays between hospitalization and death (14 days); they had no microthrombi.

Fifteen patients had signs of chronic ischemic cardiomyopathy of different severities and 2 patients had signs of acute myocardial infarction; there was no evidence of contraction bands or myocarditis. Histological evaluation of the kidneys was limited because of moderate to severe post-mortem autolysis; occasional hemosiderin granules were observed in the tubular epithelium in 9 patients and pigmented casts in 12. In the medulla, edematous expansion of the interstitial space without significant inflammation was observed in 4 patients. Chronic renal lesions (i.e., nodular mesangial expansion and arteriolar hyalinosis, glomerulosclerosis, or chronic pyelonephritis)

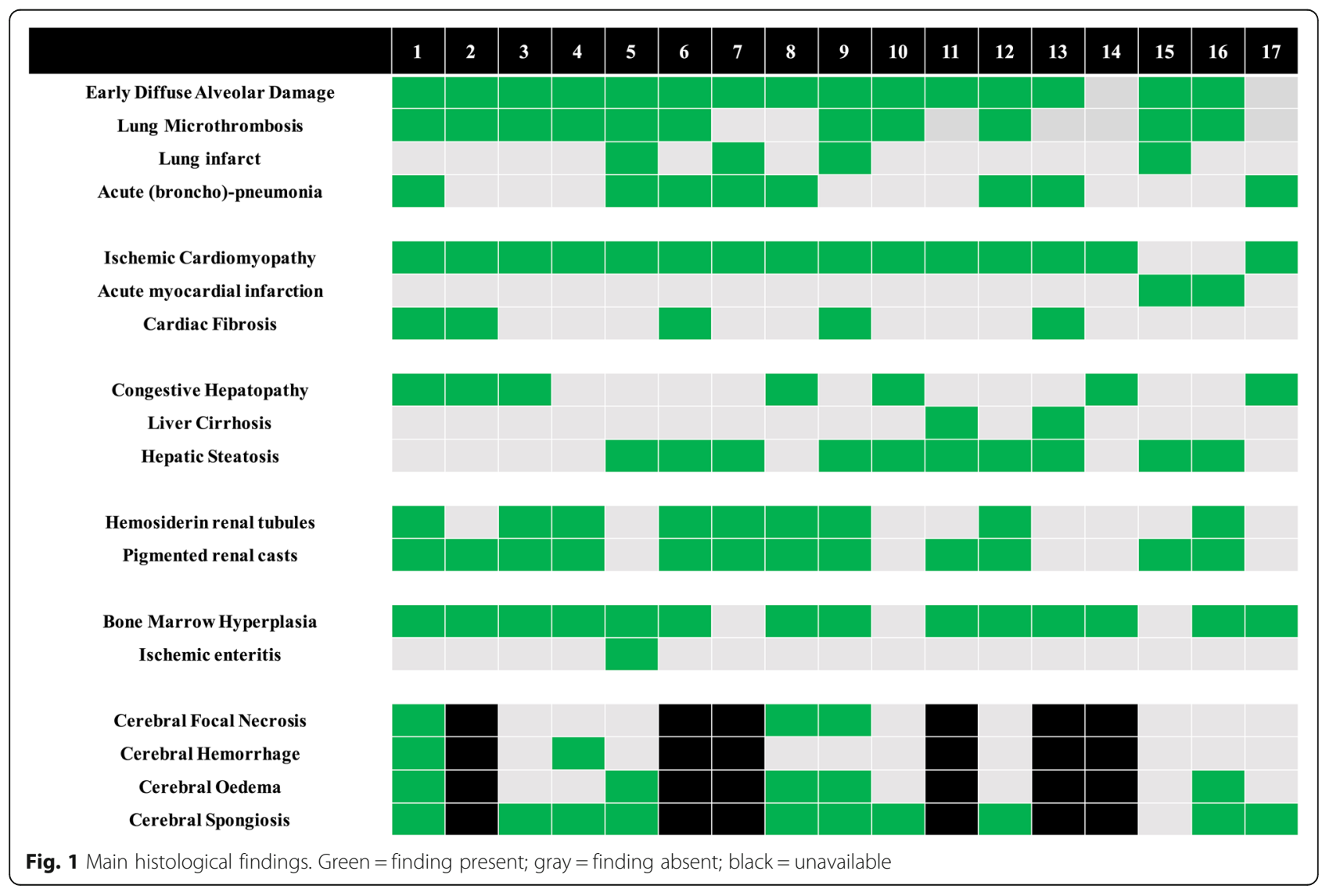



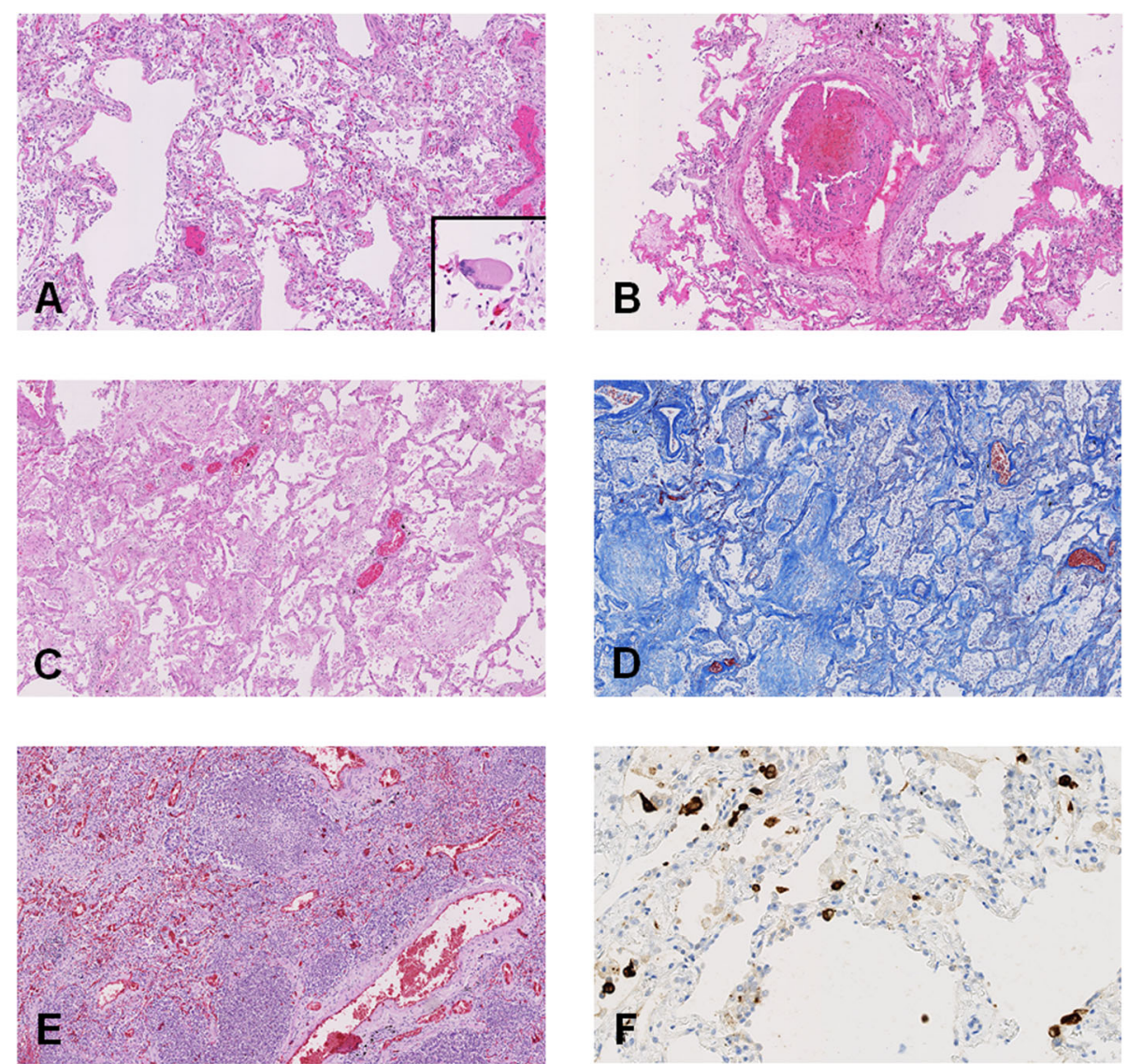

Fig. 2 Pulmonary histological findings. a Early-stage diffuse alveolar damage (DAD): hyaline membrane (H\&E, $\times 50$ magnification) with a zoom on a giant cell ( $\times 100$ magnification). b Fibrin thrombi in a pulmonary artery ( $H \& E, \times 50$ magnification). $\mathbf{c}$ Late-stage DAD: fibroblastic proliferation ( $H \& E, \times 50$ magnification). d Late-stage DAD: fibroblastic proliferation (Trichrome staining, $\times 50$ magnification). e Acute pneumonia (H\&E, $\times 50$ magnification). f Anti-SARS-CoV immunohistochemistry (IHC)-positive cells ( $\times 200$ magnification)

were also observed; no microthrombi were identified, but one patient had a thrombus in an interlobar artery.

Liver examination revealed congestive hepatopathy and steatosis, but no patchy necrosis, hepatitis, or lobular lymphocytic infiltrate. The histological changes in the abdominal organs including the esophagus, stomach, and colon are reported in Additional file 3 (Table S2); most of the findings were related to chronic underlying diseases, except for one case of ischemic enteritis.

Brain samples showed cerebral hemorrhage or hemorrhagic suffusion $(n=8)$, focal ischemic necrosis $(n=3)$, edema and/or vascular congestion $(n=5)$, and diffuse or focal spongiosis $(n=10)$. We found no evidence of viral encephalitis or vasculitis, isolated neuronal necrosis, or perivascular lymphocytic infiltration.

\section{SARS-CoV-2 detection in the lungs by IHC}

SARS-CoV-2 was identified by IHC in the lungs of 11 of the 17 patients (Fig. 3). However, there was large variability in the distribution of SARS-CoV-2-positive cells in the lung parenchyma.

\section{SARS-CoV-2 detection by RT-PCR}

SARS-CoV-2 RNA was detected in at least one organ from every patient (Fig. 4). In the lung, RT-PCR was positive in 16 patients, with threshold cycle $(\mathrm{Ct})$ values varying from 16.02 to 33.03. Viral RNA was also detected in the heart $(n=14)$, the liver $(n=14)$, the bowel $(n=14)$, the spleen $(n=11)$, and the kidney $(n=$ 10 ), as well as in 9 of the 11 cerebral samples. Ct values for non-pulmonary organs ranged from 28.67 to 35.11 . Eight patients had positive RT-PCR in all tested organs.

\section{Discussion}

This post-mortem study showed several histopathological abnormalities in COVID-19 non-survivors; however, none of the findings was specific for direct viral injury, even though SARS-CoV-2 was detected in all examined organs using RT-PCR. We decided to perform complete autopsies rather than other techniques such as post-mortem core biopsies, so as to obtain a better overview of all organs, especially the lungs (we collected 6 samples from each lobe). This approach enabled us to 


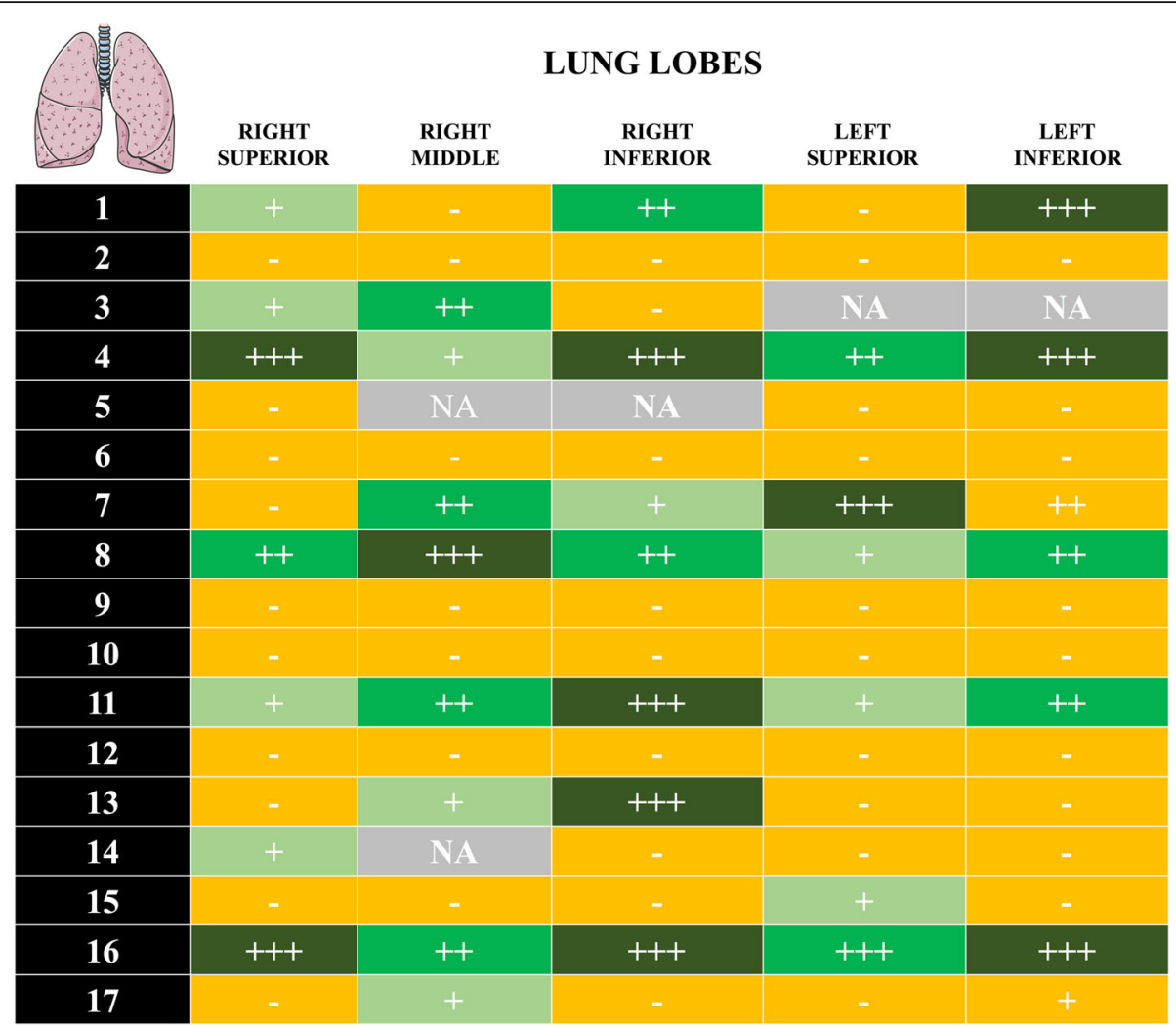

Fig. 3 Detection of SARS-CoV-2 by immunohistochemistry (IHC) in FFPE post- mortem lung samples of 17 patients. Semi-quantitative evaluation: " - " negative result; " + " scattered positive cells (between 1 and $<5$ positive cells/whole slide); " ++ " positive isolated cells (> 5 cells/whole slide, but no foci); " +++ " foci of positive cells (more than 10 positive cells in one $\times 200$ field). NA, not available

document the considerable heterogeneity of histological lesions and of SARS-CoV-2 spread through the body.

The diagnosis of SARS-CoV-2-related organ injury is challenging; post-mortem histological findings were heterogeneous and often associated with chronic underlying diseases. In a previous autopsy study in COVID-19 patients [3], the authors reported that DAD associated with viral pneumonia was almost impossible to distinguish from that caused by bacterial pneumonia. No obvious intranuclear or intracytoplasmic viral inclusions were identified in another report [6]. Desquamation of pneumocytes and hyaline membrane formation are frequently described in ARDS of many different causes, especially in early-phase ARDS [13]. The presence of multinucleated cells with nuclear atypia is used to diagnose herpes virus infection in daily practice. As in previous reports $[6,14]$, we also observed the presence of multinucleated cells within lung alveoli in three patients; however, the significance of multinucleated cells is unclear and may not be specific of SARS-CoV-2 infection [15]. Finally, some of the microscopic features of these patients are compatible with organ changes secondary to shock or systemic inflammation and no histological finding could be specifically ascribed to SARS-CoV-2.
In the absence of typical post-mortem viral features, our results show that RT-PCR is feasible on FFPE blocks and could be used in post-mortem analyses to identify the presence of SARS-CoV-2 in multiple organs and to understand the spread of the virus within the human body. The discordant RT-PCR and IHC results for detection of SARS-CoV2 in the lungs may be explained by the different sensitivity of these assays, which was higher for the RT-PCR, whereas low-level viral replication might not be detected by IHC. Moreover, IHC was based on the only available antibodies, which are targeted against SARS-CoV. New antibodies against SARS-CoV-2 need to be developed to improve the accuracy of IHC in the analysis of tissue samples from suspected or confirmed COVID-19 patients.

Most of the previous post-mortem studies in COVID-19 patients were conducted using needle biopsies and were therefore rather limited in terms of sampling; our complete autopsy analysis identified considerable heterogeneity of SARS-CoV-2 spread through the human body and provides a more accurate description of macroscopic and microscopic organ alterations. As for previous coronavirus diseases $[16,17]$, the lungs are the most affected organs in COVID-19. However, DAD findings were highly 


\begin{tabular}{|c|c|c|c|c|c|c|c|}
\hline & LUNGS & HEART & SPLEEN & LIVER & KIDNEY & BOWEL & BRAIN \\
\hline 1 & + & + & - & + & + & + & + \\
\hline 2 & + & - & - & $\mathbf{N C}$ & - & - & $\mathbf{N A}$ \\
\hline 3 & + & + & + & + & - & - & + \\
\hline 4 & + & + & - & + & - & + & + \\
\hline 5 & + & - & - & - & - & - & - \\
\hline 6 & + & - & - & + & + & + & NA \\
\hline 7 & + & + & + & + & - & + & NA \\
\hline 8 & + & + & + & + & + & + & + \\
\hline 9 & + & + & + & + & + & + & + \\
\hline 10 & + & + & + & + & + & + & + \\
\hline 11 & + & + & + & + & + & + & NA \\
\hline 12 & + & + & + & + & + & + & + \\
\hline 13 & + & + & + & + & + & + & $\mathbf{N A}$ \\
\hline 14 & + & + & + & + & + & + & $\mathbf{N A}$ \\
\hline 15 & - & + & $\mathbf{N C}$ & + & - & + & - \\
\hline 16 & + & + & + & + & + & + & + \\
\hline 17 & + & + & + & - & - & + & + \\
\hline
\end{tabular}

heterogeneous, including both early-onset and additional late lesions. This finding could be explained by the heterogeneity of the pulmonary injury, including compliant lungs in the early phase and a more dense and non-recruitable lung in the late phase [18]. As some patients died outside the ICU without receiving mechanical ventilation, we could not estimate lung compliance before death. The heterogeneity could also reflect different treatments (e.g., fluid administration or corticosteroids) or different complications; as an example, half of the patients had concomitant acute pneumonia and it is difficult to conclude whether the DAD reflected the natural time-course of the viral disease or was secondary to superimposed complications, such as nosocomial infections. In a recent report, needle post-mortem biopsies suggested that COVID-19 is not associated with DAD but rather with an acute fibrinous and organizing pneumonia (AFOP), consequently requiring corticoid treatment [19]. A diagnosis of AFOP is based on the absence of hyaline membranes and the presence of alveolar fibrin balls; however, hyaline membranes are heterogeneously distributed in the lung parenchyma with DAD and complete lung analysis, not just biopsies, are necessary to exclude their presence. Moreover, AFOP may be a fibrinous variant of DAD [20]. The limitation of lung biopsy was also shown in another study, in which only $50 \%$ of lung samples were positive for SARS-CoV-2 using RT-PCR [21], when compared to almost $100 \%$ in our series. In addition, we did not find specific "endothelitis" as previously reported in a small case series [4]. Considering the heterogeneity of postmortem COVID-19 associated lesions, molecular and IHC assessments are mandatory in the histological analysis of COVID-19 tissue samples.

Patients with COVID-19 often have altered coagulation and a prothrombotic status, with the possible development of acute pulmonary embolism (PE) [22]. In our study, three patients had PE, already diagnosed before death. Four patients had pulmonary infarction. In a previous study, acute PE was considered as the main cause of death in four patients [3]; however, the inclusion of patients who died before hospital admission and the lack of specific thromboprophylaxis during the hospital stay may account for the differences in the severity of $\mathrm{PE}$ when compared to our study. Although we frequently observed the presence of microthrombi in the lung parenchyma, this feature is also reported in other forms of ARDS, regardless of etiology [13, 23]. As such, whether diffuse pulmonary thrombosis is a main contributor of the fatal course of severe hypoxemia in COVID-19 
patients remains to be further studied. In a systematic review of pathological findings in COVID-19, Polak et al. [24] identified a timeline in the histopathological findings in the lung, with epithelial (DAD, denudation and reactive pneumocytes atypia) and vascular (microvascular damage, thrombi, intra-alveolar fibrin deposits) changes present at all stages of the disease, but fibrotic changes (interstitial fibrous changes) only appearing about 3 weeks after the onset of symptoms. Few patients had fibrosis at early stages, and in these cases, it was likely because of pre-existing lung disease. Our results are consistent with those of Polak et al. [24] except for the lack of late fibrotic changes, which may be related to the use of anti-inflammatory drugs at high doses for nearly all our patients $(16 / 17)$.

We did not observe specific viral organ injury, such as myocarditis, hepatitis, or encephalitis. The cases of "acute cardiac injury" reported in COVID-19 clinical studies [25] do not necessarily translate into myocarditis or acute myocardial ischemia (only two had acute myocardial ischemia), similar to data reported in septic patients (i.e., elevated troponin without overt cardiac ischemia) [26]. However, using RT-PCR, we found the virus in almost all the examined organs; this suggests that the virus can bind to most cells, probably via the ACE2 receptor, which is ubiquitous, but may not directly cause organ injury. As extra-pulmonary direct viral injury (e.g., encephalitis, hepatitis, or myocarditis) has only been reported in very few cases, we suggest that SARS-CoV-2 infection may be just the trigger for an overwhelming host response, which could secondarily result in COVID-19-associated organ dysfunction. As RT-PCR might just detect residual viral genome, it remains unclear whether this represents active viral replication into the tissues or previous cellular infection, without clinically relevant significance [27].

This study has several limitations: (i) we only included patients who had had a positive RT-PCR on nasopharyngeal swab and/or broncho-alveolar lavage. To ensure that only true positive cases were enrolled, we decided not to include three patients who had had thoracic CTscan findings suggestive of COVID-19 but had negative RT-PCR results. This limitation in our study reflects the difficulty of diagnosing COVID-19 on a clinical basis; (ii) the sample size was relatively small, and autopsies were only carried out from 72 to $96 \mathrm{~h}$ after death. This delay did not allow us to properly analyze the gastrointestinal tract and kidneys, which showed signs of autolysis; in particular, acute tubular injury in the proximal tubules was indistinguishable from autolysis; (iii) we could not determine the time-course and/or sequence of organ spread of the virus and no specific hypothesis regarding how SARS-CoV-2 spreads (e.g., hematogenously) could be identified; and (iv) the time to death differed from patient to patient as did the course of the disease and treatments received, which limits a precise clinicalpathological correlation of histological findings related to COVID-19. Finally, we did not evaluate specific mechanisms involved in the pathogenesis of organ injury.

\section{Conclusion}

These results underline the heterogeneity of organ injuries during COVID-19 disease and the absence of specific SARS-CoV-2 lesions. Using RT-PCR, SARS-CoV-2 could be detected in all organs, even those without evident microscopic lesions.

\section{Supplementary information}

Supplementary information accompanies this paper at https://doi.org/10. 1186/s13054-020-03218-5.

Additional file 1. Critical care-autopsy-Covid. Additional material. Procedure to obtain brain samples.

Additional file 2: Critical care-autopsy-Covid. Additional Table S1. Laboratory findings on the day of admission.

Additional file 3: Critical care-autopsy-Covid. Additional Table S2. Detailed histological findings in all patients.

\section{Abbreviations}

ACE2: Angiotensin converting enzyme 2; AFOP: Acute fibrinous and organizing pneumonia; AKI: Acute kidney injury; ARDS: Acute respiratory distress syndrome; COVID-19: Coronavirus disease 2019; Ct: Threshold cycle; DAD: Diffuse alveolar damage; FFPE: Formalin-fixed paraffin-embedded; H\&E: Hematoxylin and eosin; IHC: Immunohistochemistry; IQRs: Interquartile ranges; MERS-CoV: Middle East respiratory syndrome coronavirus;

PAS: Periodic acid-Schiff; PE: Pulmonary embolism; RT-PCR: Real-time reversetranscription polymerase chain reaction; SARS-CoV: Severe acute respiratory syndrome coronavirus

\section{Acknowledgments}

The authors thank Nathalie Lijsen, Christophe Valleys, Georges Lacroix, Barbara Alexiou, Dominique Penninck, Nicole Haye, and Audrey Verrellen for technical and logistic supports; Prof Frédéric Schuind and Dr. Djamel-Eddine Yahia-Cherif for neurosurgical procedure; Egor Zindy (DIAPath, ULB) for proofreading the paper; and Dr. Marie-Paule Van Craynest for trainees' supervision.

\section{Authors' contributions}

IS had the idea for and designed the study and had full access to all the data in the study and takes responsibility for the integrity of the data and the accuracy of the data analysis. IS, FT, JLV, and CD drafted the paper. MR, $C V, L L, P L, M L R, C M, A L T$, JCG, LP, RDM, SD, SR, ND, LP and OD collected the data. MR, ND, and RDM did the analysis, and all authors critically revised the manuscript for important intellectual content and gave final approval for the version to be published. All authors agree to be accountable for all aspects of the work in ensuring that questions related to the accuracy or integrity of any part of the work are appropriately investigated and resolved.

\section{Funding}

This study received financial support from Fonds Y. Boël (Brussels, Belgium), Fonds Erasme pour la Recherche Médicale (Brussels, Belgium), and "Appel à projet Spécial COVID-19 - ULB" (Brussels, Belgium). The CMMI is supported by the European Regional Development Fund and the Walloon Region of Belgium (Wallonia-biomed; grant no. 411132-957270; project "CMMI-ULB" support the Center for Microscopy and Molecular Imaging and its DIAPath department). CD is a Senior Research Associate with the F.N.R.S. (Belgian National Fund for Scientific Research). 


\section{Availability of data and materials}

The data that support the findings of this study are available from the corresponding author on reasonable request. Participant data without names and identifiers will be made available after approval from the corresponding author and local Ethics Committee. The research team will provide an email address for communication once the data are approved to be shared with others. The proposal with a detailed description of study objectives and statistical analysis plan will be needed for the evaluation of the reasonability to request for our data. Additional materials may also be required during the process.

\section{Ethics approval and consent to participate}

The study protocol was approved by the local ethics committee (Erasme Hospital P2020/218). The ethical committee has waived the need for written informed consent.

\section{Consent for publication}

Not applicable

\section{Competing interests}

The authors declare that they have no competing interests.

\section{Author details}

'Department of Pathology, Erasme Hospital, Université Libre de Bruxelles (ULB), Route de Lennik 808, 1070 Brussels, Belgium. ${ }^{2}$ Centre Universitaire inter Régional d'expertise en Anatomie Pathologique Hospitalière (CurePath, CHIR EC, CHU Tivoli, ULB), Rue de Borfilet 12A, 6040 Jumet, Belgium. ${ }^{3}$ Immunodeficiency Treatment Unit, Erasme Hospital, Université Libre de Bruxelles (ULB), Route de Lennik 808, 1070 Brussels, Belgium. ${ }^{4}$ Department of Neurosurgery, Erasme Hospital, Université Libre de Bruxelles (ULB), Route de Lennik 808, 1070 Brussels, Belgium. ${ }^{5}$ Department of Intensive Care, Erasme Hospital, Université Libre de Bruxelles (ULB), Route de Lennik 808, 1070 Brussels, Belgium. '́ Laboratory of Image Synthesis and Analysis (LISA), Université Libre de Bruxelles (ULB), CPI 165/57, Avenue Franklin Roosevelt 50, 1050 Brussels, Belgium. ${ }^{7}$ DIAPath, Center for Microscopy and Molecular Imaging, Université Libre de Bruxelles (ULB), CPI 305/1, Rue Adrienne Bolland, 8, 6041 Gosselies, Belgium.

Received: 18 May 2020 Accepted: 30 July 2020

\section{Published online: 12 August 2020}

\section{References}

1. Guan WJ, Ni ZY, Hu Y, Liang WH, Ou CQ, He JX, et al. Clinical characteristics of coronavirus disease 2019 in China. N Engl J Med. 2020;382:1708-20.

2. Hoffmann M, Kleine-Weber H, Schroeder S, Krüger N, Herrler T, Erichsen S, et al. SARS-CoV-2 cell entry depends on ACE2 and TMPRSS2 and is blocked by a clinically proven protease inhibitor. Cell. 2020;181:1-10.

3. Wichmann D, Sperhake JP, Lütgehetmann M, Steurer S, Edler C, Heinemann $A$, et al. Autopsy findings and venous thromboembolism in patients with covid-19: a prospective cohort study. Ann Intern Med. 2020. Epub ahead of print. https://doi.org/10.7326/M20-2003.

4. Varga Z, Flammer AJ, Steiger P, Haberecker M, Andermatt R, Zinkernagel AS, et al. Endothelial cell infection and endotheliitis in COVID-19. Lancet. 2020; 395:1417-8.

5. Chen T, Wu D, Chen H, Yan W, Yang D, Chen G, et al. Clinical characteristics of 113 deceased patients with coronavirus disease 2019: retrospective study. BMJ. 2020. Epub ahead of print. https://doi.org/10.1136/bmj.m1091.

6. Xu Z, Shi L, Wang Y, Zhang J, Huang L, Zhang C, et al. Pathological findings of COVID-19 associated with acute respiratory distress syndrome. Lancet Respir Med. 2020;8:420-2.

7. Barton LM, Duval EJ, Stroberg E, Ghosh S, Mukhopadhyay S. COVID-19 autopsies, Oklahoma. USA Am J Clin Pathol. 2020;153:725-33.

8. ARDS Definition Task Force, Ranieri VM, Rubenfeld GD, Thompson BT, Ferguson ND. Caldwell E, fan E, et al. acute respiratory distress syndrome: the Berlin Definition. JAMA. 2012;307:2526-33.

9. Kellum JA, Lameire N, KDIGO AKI. Guideline Work Group. Diagnosis, evaluation, and management of acute kidney injury: a KDIGO summary (part 1). Crit Care. 2013;17:204.

10. Procédure pour les hôpitaux: prise en charge d'un patient possible ou confirmé COVID-19.https://epidemio.wiv-isp.be/ID/Documents/Covid19/ COVID-19_procedure_deaths_FR.pdf. Accessed 03/16/20.
11. D'Haene N, Meléndez B, Blanchard O, De Nève N, Lebrun L, Van Campenhout C, et al. Design and validation of a gene-targeted, nextgeneration sequencing panel for routine diagnosis in gliomas. Cancers (Basel). 2019:11:773.

12. Corman VM, Landt O, Kaiser M, Molenkamp R, Meijer A, Chu DK, et al. Detection of 2019 novel coronavirus (2019-nCoV) by real-time RT-PCR. Euro Surveill. 2020;25:2000045.

13. de Hemptinne Q, Remmelink M, Brimioulle S, Salmon I, Vincent JL. ARDS: a clinicopathological confrontation. Chest. 2009;135:944-9.

14. Menter T, Haslbauer JD, Nienhold R, Savic S, Hopfer H, Deigendesch N, et al. Post-mortem examination of COVID19 patients reveals diffuse alveolar damage with severe capillary congestion and variegated findings of lungs and other organs suggesting vascular dysfunction. Histopathology. 2020. Epub ahead of print. https://doi.org/10.1111/his.14134.

15. Franks TJ, Chong PY, Chui P, Galvin JR, Lourens RM, Reid AH, et al. Lung pathology of severe acute respiratory syndrome (SARS): a study of 8 autopsy cases from Singapore. Hum Pathol. 2003;34:743-8.

16. Nicholls JM, Poon LL, Lee KC, Ng WF, Lai ST, Leung CY, et al. Lung pathology of fatal severe acute respiratory syndrome. Lancet. 2003;361: $1773-8$.

17. Hwang D, Chamberlain D, Poutanen S, Low DE, Asa SL, Butany J. Pulmonary pathology of severe acute respiratory syndrome in Toronto. Mod Pathol. 2005;18:1-10.

18. Gattinoni L, Chiumello D, Rossi S. COVID-19 pneumonia: ARDS or not ? Crit Care. 2020;24:154

19. The Lille COVID-19 ICU and Anatomopathology Group, Copin M-C Parmentier E, Duburcq T, Poissy J, Mathieu D. Time to consider histologic pattern of lung injury to treat critically ill patients with COVID-19 infection. Intensive Care Med. 2020;46:1124-6.

20. Santos C, Oliveira RC, Serra P, Baptista JP, Sousa E, Casanova P, et al. Pathophysiology of acute fibrinous and organizing pneumonia - clinical and morphological spectra. Pathophysiology. 2019;26:213-7.

21. Wang D, Hu B, Hu C, Zhu F, Liu X, Zhang J, et al. Clinical characteristics of 138 hospitalized patients with 2019 novel coronavirus-infected pneumonia in Wuhan, China. JAMA. 2020. Epub ahead of print. doi: https://doi.org/10. 1001/jama.2020.1585.

22. Llitjos JF, Leclerc M, Chochois C, Monsallier JM, Ramakers M, Auvray M, et al. High incidence of venous thromboembolic events in anticoagulated severe COVID-19 patients. J Thromb Haemost. 2020;18:1743-6.

23. Chang JC. Acute respiratory distress syndrome as an organ phenotype of vascular microthrombotic disease: based on hemostatic theory and endothelial molecular pathogenesis. Clin Appl Thromb Hemost. 2019;25: 1076029619887437.

24. Polak SB, Van Gool IC, Cohen D, von der Thüsen JH, van Paassen J. A systematic review of pathological findings in COVID-19: a pathophysiological timeline and possible mechanisms of disease progression [published online ahead of print, 2020 Jun 22]. Mod Pathol 2020;1-11. doi:https://doi.org/10.1038/s41379-020-0603-3.

25. Shi S, Qin M, Shen B, Cai Y, Liu T, Yang F, et al. Association of cardiac injury with mortality in hospitalized patients with COVID-19 in Wuhan, China. JAMA Cardiol. 2020. Epub ahead of print. doi: https://doi.org/10.1001/ jamacardio.2020.0950.

26. Smeding L, Plötz FB, Groeneveld AB, Kneyber MC. Structural changes of the heart during severe sepsis or septic shock. Shock. 2012;37:449-56.

27. Wölfel R, Corman VM, Guggemos W, Seilmaier M, Zange S, Müller MA, et al. Virological assessment of hospitalized patients with COVID-2019. Nature. 2020;581:465-9.

\section{Publisher's Note}

Springer Nature remains neutral with regard to jurisdictional claims in published maps and institutional affiliations. 